DOI: 10.20472/IAC.2017.032.011

JOANNA DZIAŁO

University of Lodz, Faculty of Economics and Sociology, Poland

BEATA GUZIEJEWSKA

University of Lodz, Faculty of Economics and Sociology, Poland

\title{
NUMERICAL FISCAL RULES: FRAMEWORK OR BARRIER FOR PUBLIC POLICYMAKING?
}

\begin{abstract}
:
The paper aims to assess the role of fiscal rules in the process of consolidating public finances and maintaining macroeconomic stability in the EU Member States in the period of the economic crisis. Additionally, the paper presents the case study on the efficiency of fiscal rules at the self-government (local) level in Poland. The article puts forward the thesis that fiscal rules were not an effective instrument for ensuring fiscal discipline in times of crisis. It presents the most important issues of the process of evolution of the rules during the crisis. A review and an analysis of legislation and literature on reforms implemented in the area of fiscal rules, confirms this thesis. The paper points to the need to create such fiscal rules that could contribute not only to fiscal stability but also to macroeconomic stability of the economy and concludes with recommendations for the creation of effective fiscal rules and their desirable features. The rules should be based on the structural balance or the over the cycle balance (but, in order for such rules to be effective, the structural deficit should be relatively low). Effective enforcement of the rules is necessary as well as a strong legal basis for the rules.
\end{abstract}

\section{Keywords:}

fiscal policy, fiscal rules, public debt, budget deficit

JEL Classification: E62, H74 


\section{Introduction}

One of the most important factors affecting the effectiveness of fiscal policy conducted in a country is the right choice of fiscal rules. The fulfillment of this condition is particularly important during an economic crisis, manifested, among others, in a drastic deterioration of the state of the public finance sector. The economic crisis revealed the need to reform the previously binding fiscal rules and the need to strengthen their enforceability in order to turn the rules into the instrument which, on the one hand, is a tool to ensure fiscal stability, and on the other, a tool which supports the economic growth.

The paper aims to assess whether the "pre-crisis" fiscal rules were an effective instrument in stabilising public finances in the EU countries. In addition, it will present the most important aspects of the process of evolution of the rules during the economic crisis and provide suggestions for the future direction of changes in the rules aimed at increasing their effectiveness in improving fiscal and macroeconomic stability. Finally, the paper provides the case-study on the effectiveness of fiscal rules in Poland at the local (self-government) level.

\section{"Pre -crisis" fiscal rules in the European Union}

Fiscal rules, understood as a quantitative restriction on the deficit level, public debt, government revenue or expenditure, usually stipulated in the Constitution or the relevant law, are one of the factors favouring the sound fiscal policy [Schick, 2010]. Fiscal rules may be introduced for several reasons. One of the reasons is to ensure macroeconomic stability in the economy and maintain a stable fiscal policy in the long term. The rules are also aimed at reducing negative externalities of pursuing an independent fiscal policy by the European Union countries). However, during an economic crisis, the primary objective of fiscal rules is to reduce excessive deficit and debt levels as well as to improve the credibility of the fiscal policy conducted.

The fiscal rules laid down in the Treaty of Maastricht proved to be quite effective and caused a visible decline in the deficit and debt levels in many EU countries. In 1993, the average deficit in the euro area candidate countries amounted to $5.5 \%$ of GDP, while in 1997 it amounted to only $2 \%$ of GDP. In 1999, all the countries met the required criteria [Działo, 2009]. However, since the entry into force of the European Monetary Union (2000), the Member States which joined the euro area have no longer adhered to the convergence criteria and have clearly loosened their fiscal policies. As over time the rules laid down in the Treaty of Maastricht came to be seen as not sufficiently precise, new fiscal rules enshrined in the Stability and Growth Pact (SGP) were adopted in 1997. The Pact upheld the fiscal rules introduced by the Treaty of Maastricht and in addition also required each of the countries with the common currency to achieve a budgetary position of close to balance or in surplus in the medium term (during a complete business cycle) - the so called Medium-Term Budgetary Objective (MTO). The Pact also clarified the exceptions relating to the determination of deficit as excessive, as well as detailed the two stages of the excessive deficit procedure: 
preventive and repressive. Moreover, it introduced the possibility of imposing fines for maintaining the deficit at excessive levels. However, the SGP proved to be not a very effective mechanism to enforce a sound fiscal policy in the EU Member States. Undoubtedly, it was mostly due to the fact that a relatively great deal of freedom for discretionary decisions was left. For example, the European Commission could decide not to initiate disciplinary procedures if it determined that the exceeded limits were due to the occurrence of a temporary, exceptional emergency situation [Alesina, Giavazzi, 2002].

Assessing the effectiveness of the pre-crisis fiscal rules in disciplining the fiscal policy, it should be noted that, generally speaking, their theoretical framework was correct, and the greatest difficulty was associated with ensuring compliance. The mechanism of sanctions contained in the SGP proved to be ineffective and the decision of the European Council of November 2003 not to take sanctions against France and Germany within the framework of the excessive deficit procedure was the most obvious example. The decision was perceived as a blatant example of dependency of the provisions of the SGP on political factors [Jędrzejowicz, Kitala, Wronka, 2009].

\section{Fiscal rules in the EU during the economic crisis}

One of the effects of the economic crisis was a rapid deterioration of public finances in most EU Member States. A severe recession led to the need to increase the scope of the discretionary policy and to provide financial support for economies from national budgets, which in turn dramatically increased budget deficits and public debts in many EU countries.

Table 1. Public debt and public sector deficit in the EU countries

\begin{tabular}{|l|l|l|l|l|l|l|l|l|l|l|}
\hline & $\mathbf{2 0 0 6}$ & $\mathbf{2 0 0 7}$ & $\mathbf{2 0 0 8}$ & $\mathbf{2 2 0 9}$ & $\mathbf{2 0 1 0}$ & $\mathbf{2 0 1 1}$ & $\mathbf{2 0 1 2}$ & $\mathbf{2 0 1 3}$ & $\mathbf{2 0 1 4}$ & $\mathbf{2 0 1 5}$ \\
\hline \multicolumn{1}{|l|}{ Public sector deficit } \\
\hline $\begin{array}{l}\text { EU } \\
\text { countries } \\
\text { (28) }\end{array}$ & -1.6 & -0.9 & -2.4 & -6.6 & -6.4 & -4.6 & -4.3 & -3.3 & -3.0 & -2.4 \\
\hline $\begin{array}{l}\text { Euro } \\
\text { zone (19) }\end{array}$ & -1.5 & -0.6 & -2.2 & -6.3 & -6.2 & -4.2 & -3.6 & -3.0 & -2.6 & -2.1 \\
\hline
\end{tabular}




\begin{tabular}{|l|c|c|c|c|c|c|c|c|c|c|}
\hline $\begin{array}{l}\text { EU } \\
\text { countries } \\
(\mathbf{2 8 )}\end{array}$ & 61.6 & 59.0 & 62.2 & 74.6 & 77.9 & 82.5 & 85.4 & 87.2 & 88.0 & 85.2 \\
\hline $\begin{array}{l}\text { Euro } \\
\text { zone (19) }\end{array}$ & 68.6 & 66.4 & 70.2 & 80.0 & 83.0 & 87.5 & 90.8 & 92.7 & 93.9 & 97.0 \\
\hline
\end{tabular}

Source: Eurostat, http://appsso.eurostat.ec.europa.eu/nui/submitViewTableAction.do, access:

27.01.2017

As a result, many EU Member States were no longer able to fulfil the applicable fiscal rules, both the EU (supranational) and national ones. Therefore, the EU began to seek new solutions to improve fiscal discipline, carrying out reforms of supranational fiscal rules. On the other hand, many Member States applying national rules eased the criteria (often for a limited time) of compliance with the rules or introduced new rules.

In 2010, actions were taken to carry out further reforms of the SGP in order to adapt it better to the existing economic realities. As a result, there has been an increase in the importance of the public debt criterion. Due to the new solutions, the EU can take actions when the budget deficit does not exceed $3 \%$ of GDP, but the public debt is above $60 \%$ of GDP. In addition, the so-called "European Semester" was established, whereby the Member States may seek the EU's assessment of their national budgetary plans and national reform programmes in the course of their preparation [Reinforcing Economic Policy Coordination, COM(2010)].

Successive reforms were carried out in 2011 (the so-called six-pack), in response to the fiscal crisis in Greece, Ireland and Portugal. The principle of "a satisfactory pace of debt reduction" was then introduced for countries exceeding 60\% of GDP. Noncompliance may result in financial sanctions [Działo, 2013].

The next step on the path of reforms was the signing of the Fiscal Compact on 2 March 2012. The most important provisions of the Compact include the new golden rule of the budget balance according to which the structural budget deficit cannot exceed $0.5 \%$ of the country's nominal GDP. The strengthening of the EU's control over Member States' fiscal discipline by including in the national law of the EU countries obligatory implementation of the MTO is considered a very significant and innovative solution. Enforceability of the proposed solutions has also been strengthened as the EC's consent is no longer necessary to initiate the excessive deficit procedure and sanctions are applied automatically when the rules are violated [Kaliszuk, 2012]. Two additional mechanisms intended only for the euro area countries, the so-called twopack, adopted on 30 May 2013, should also be mentioned. The first regulation lays down specific rules with regard to countries covered by the excessive deficit procedure. The second regulation lays down rules for enhanced surveillance in countries experiencing serious difficulties with maintaining financial stability and those that 
receive financial assistance [European Commission, http://www.europa.eu (17.07.2015)].

\section{Desired features of post-crisis fiscal rules}

As mentioned earlier, fiscal rules during the times of the subsequent economic crisis, proved to be ineffective. Most EU Member States sacrificed their fiscal stability for the sake of restoring their macroeconomic balance. Unfortunately, such actions resulted in a further increase of deficit and debt levels and thus forced a search for solutions to promote both fiscal and economic balance.

The economic crisis has shown that the EU has not developed fiscal rules that would satisfy the above-mentioned criterion. Both deficit rules and debt rules laid down in the Maastricht Treaty act pro-cyclically, as rigid limits on deficit/debt do not facilitate conducting a prudent fiscal policy in times of prosperity, while forcing fiscal retrenchment during a slowdown/recession. Fiscal rules based on cyclically adjusted balance (the structural balance) offer the possibility to mitigate cyclical fluctuations since they eliminate the impact of automatic stabilisers, allowing the implementation of a flexible fiscal policy. However, the main problem with fulfilling such a rule is too high structural deficits in most EU countries. In order for the fiscal policy to stabilize the economic situation (not to be pro-cyclical), the structural deficit should be kept as low as possible. Then, even in times of recession, when there is the cyclical deficit, the actual (cyclical and structural) deficit has a good chance not to exceed the threshold of $3 \%$ of GDP. This means that with the low structural deficit, the actual deficit is mainly determined by the level of the cyclical deficit. If this condition is fulfilled, fiscal stability and macroeconomic stability are ensured primarily through the operation of automatic stabilisers of the economic cycle. The impact of the stabilisers would provide funding of the structural deficit with the cyclical surplus which would accrue in times of economic prosperity [Próchnicki, 2012].

The problem is, however, that the mechanism fails when the structural deficit is excessive. In periods of recession, a high structural deficit would force conducting a restrictive fiscal policy so that the actual deficit should not exceed a designated threshold. As a result, the fiscal policy instead of being countercyclical, would become procyclical. The structural deficit of the EU Member States for many years had remained at a relatively high level, which resulted in a high actual deficit, especially during the economic crisis. In conclusion, in order to ensure fiscal and macroeconomic stability, the structural deficit should be low for the entire duration of the economic cycle. In this case, the structural balance rule will have the desirable features, i.e. it will serve to stabilise public finances as well as the economy [Wójtowicz, 2011].

However, the structural balance of the budget is also not an optimal solution as it is not safe from the impact of discretionary actions taken by the state to stabilize its economy. Therefore, a better solution is to extend the time horizon of the rules on the budget balance for the entire cycle. Then the adopted limits refer to the average level of the 
nominal over the cycle budget balance. Thus constructed rules are much more flexible as the effects of expansionary discretionary measures taken during the economic crisis are offset by a corresponding tightening of the policy in the expansion phase [Balassone, Kumar, 2007].

Flexibility of fiscal rules can also be increased by defining precisely the so-called exit clauses, i.e. conditions that allow the unfulfilment of the rule. These exceptions should be clearly defined and should indicate the time and the path back to the fulfilment of the rule. This solution limits the discretion, and at the same time is conducive to macroeconomic stability. It is also important to ensure compliance with the rules. Therefore, it is so vital for fiscal rules to have strong legal foundations, i.e. to be enshrined in the Constitution or a relevant Act. The incorporation of the rules in the legal system is a tool strongly limiting the freedom of politicians in shaping the fiscal policy.

\section{Fiscal rules in self-governments: the case of Poland}

Discussing the issue of effectiveness of the fiscal rules, one should also consider the problem of multiple levels of government and their role to perform public sector activities. In the literature this problem is widely discussed as "fiscal federalism" or "decentralization" [Green J.E, 2012]. The Polish experience has demonstrated that restrictions on incurring debt constitute a fairly effective barrier for excessive indebtedness of local governments. For the last few decades the cases of bankruptcy or serious financial problems of cities and gminas have occurred incidentally. Nevertheless, excessive indebtedness of local governments has been strongly criticized in Poland. Similar criticism has been directed towards the high debt incurred for infrastructural investments at the expense of current social needs, which reflects a broader problem of the rationale behind public expenditure and a natural competition between current and investment expenditures. This problem is connected with a shortage of funds in relation to public needs.

When compared to other EU countries, the economic situation in Poland at the time of the financial crisis, looked relatively positive, which may be supported by the fact that Poland was the country that avoided the recession of 2009 and, in the subsequent years, developed at a relatively highest rate of all the EU membership states. The country has been struggling to curb the excessive budget deficit and public debt, which by 2009 had risen to the levels that triggered the excessive deficit procedure, which all the EU countries in such a situation have to undergo. The share of the self-government debt in the total amount of the public debt in Poland is not high and for the last year has remained between $5-7 \%$. What seems to be a far more serious problem that economists have pointed to is the high dynamics of the debt incurred by the local government units. The public debt at local level raised from 15.3 bln PLN in 2002 to 71.5 bln PLN in 2015. The rise in debt is primarily due to co-financing of European Union projects where the so-called own financial contribution is required. The debt, 
however, will have to be repaid in the future, which may exceed the financial capacity of the local government units as they are characterized in Poland by limited powers of taxation. In the long term, debt reduces the spending capacity of a budget as it must be repaid with the accumulated cost (interest). Moreover, in the future, communal investments may generate considerable high maintenance costs. The fiscal rules which have been in use for the local government sector in Poland for many years are primarily based on the limitations concerning debt. The types of such fiscal rules and their change in time have been laid out in Table 2.

Table 2. Fiscal rules concerning local government units in the legal state

\begin{tabular}{|c|c|c|c|c|c|c|c|c|}
\hline Fiscal rule & 2009 & 2010 & 2011 & 2012 & 2013 & 2014 & 2015 & 2016 \\
\hline $\begin{array}{l}\text { Debt rule: } \\
\text { Liabilities to } \\
\text { revenue ratio }\end{array}$ & \multicolumn{5}{|c|}{$\begin{array}{l}60 \% \\
\text { (from December } 2010 \text { the criteria defining instruments } \\
\text { included in public debt have been tightened) }\end{array}$} & \multicolumn{3}{|l|}{ none } \\
\hline $\begin{array}{l}\text { Exclusions } \\
\text { from the rule } \\
\text { of debt } \\
\text { servicing } \\
\text { costs }\end{array}$ & \multicolumn{5}{|c|}{$\begin{array}{l}\text { Repayment (principal instalments } t+\text { interest) of } \\
\text { securities and credits or loans contracted in } \\
\text { conjunction with the use of funds defined in an } \\
\text { agreement signed with an entity having at its disposal } \\
\text { European Union funds }\end{array}$} & \multicolumn{3}{|c|}{$\begin{array}{l}\text { Servicing (principal only) } \\
\text { of securities and credits or } \\
\text { loans contracted in } \\
\text { conjunction with the use } \\
\text { of funds defined in an } \\
\text { agreement signed with an } \\
\text { entity having at its } \\
\text { disposal European Union } \\
\text { funds (excluding interest) }\end{array}$} \\
\hline $\begin{array}{l}\text { Exclusions } \\
\text { from the debt } \\
\text { rule }\end{array}$ & \multicolumn{5}{|c|}{$\begin{array}{l}\text { Securities and credits or loans contracted in } \\
\text { conjunction with the use of funds defined in an } \\
\text { agreement signed with an entry having at its disposal } \\
\text { European Union funds (for financing and co- } \\
\text { financing) }\end{array}$} & & & \\
\hline $\begin{array}{l}\text { Debt } \\
\text { servicing } \\
\text { costs rule }\end{array}$ & \multicolumn{5}{|c|}{$\begin{array}{l}15 \% \\
(12 \% \text { should public debt exceed the threshold of } 55 \% \\
\text { GDP ) }\end{array}$} & \multicolumn{3}{|c|}{$\begin{array}{l}\text { System of individual } \\
\text { constrains }\end{array}$} \\
\hline
\end{tabular}




\begin{tabular}{|l|l|l|}
\hline $\begin{array}{l}\text { budget for } \\
\text { local gov. } \\
\text { units }\end{array}$ & None & Yes \\
\hline
\end{tabular}

Source: The Convergence Programme, 2012 update, Warsaw, p. 44.

The new fiscal rule introducing so called "individual" limits on debt, which took into account the capacity of a local government to repay such debt, was introduced in 2014. The new rule prohibits the local authorities from adopting a budget the accomplishment of which would cause that, in the budgetary year and in each year following the budgetary year, the ratio between payments associated with servicing of debt and the revenue would be higher than the arithmetic mean of ratios between its current revenues, calculated for the last three years, increased by the revenue from the sales of assets and decreased by current expenditure, and the total revenue of the budget. This rule is defined by the formula in Act of Public Finance (article 243). The indebtedness ratio, calculated on the basis of the value from three preceding years, on the one hand, waives the limitations binding the local governments for whom incurring even substantial financial liabilities may be an instrument of safe development policy, and on the other hand, introduces discipline for such entities which, due to high burden on revenues arising from repayment of liabilities, are obliged to be careful when drawing new credits and loans or issuing securities [Convergence Programme 2014 update, p. 64]. It is underlined that the limit of indebtedness is aimed at securing the subnational governments against excessive accumulation of payments due to debt service in relation to their revenue.

The introduction of changes in the fiscal rules related to the indebtedness of local government units in Poland has had a positive impact on balance of these entities. In the last years, in spite of the relatively poor economic growth, the number of entities which recorded deficit in the current part of the budget has been falling, and the total level of surplus in the current part of the local budgets has been growing [Convergence Programme 2014 update, p. 64]. These effects are noted in the reports from the Regional Chambers of Audit. As can be seen from the data for 2015, the current realized revenues of all the local government units exceeded, on balance, the incurred expenditure by $18,227,614$ thousand PLN. 2,762 units ( $98.4 \%$ of their total number) achieved a positive difference between the current revenues and current expenditures for a total of $18,305,491$ thousand PLN. The remaining 46 units $(1.6 \%$ of the total number) closed the budgetary year with operational deficit at a total of 77,877 thousand PLN [Report on the activities of the Regional Chambers of Audit and the execution of the budget by local government units for 2015. Part II, Warsaw 2016, p. 278]. This positive effects are very important. The subnational government plays a crucial role in the whole public sector. It is responsible for delivering public services and goods that secure the needs of local communities. Fiscal and social stability at local level determine in fact the quality of life. 


\section{Conclusions:}

Effective fiscal rules ought to combine the two following criteria: they should stabilise public finances and should not inhibit economic growth. The simultaneous fulfilment of these two conditions, seemingly contradictory, is possible with the use of rules based on the structural balance or the over the cycle balance. However, in order for such a rule to be effective, the structural deficit should be relatively low. Effective enforcement of the rules is possible by means of universality and inevitability of sanctions, as well as by ensuring the use of a control mechanism. In addition, a strong legal basis for the rules is important.

From the point of view of responsible fiscal policy the numerical fiscal rules should be the legal framework but under some conditions. First of all they should not be the barrier for public policy making, and secondly, the problem has different connections at the state and local government level because local entities do not pursue a policy of macro economy. In this context it should be underlined that sub-national governments have no autonomy on levying taxes and has no full sovereignty, especially in unitary countries. The system of local government finance in Poland is based too much on the revenues of transfer character. This refers not only to general subsidy and allocations from the central budget but also shares in income taxes, which are considered to be a transfer of general character in the theory of fiscal federalism. Local governments, which suffer from inadequate finance in relation to passed tasks, should have more competence to implement their own tax policy and thus to increase their budgets. Such a solution would be beneficial from the point of view of public choice theory and the rationalization of expenditure. It would diminish the demanding attitude towards the self-government and then raise the level of responsibility before the local taxpayers and local voters.

\section{References}

Alesina A., Giavazzi F., Pakt Stabilizacji, który destabilizuje Europę, Rzeczpospolita, 02.11.2002.

Balassone F., Kumar M.S., Cyclicality of Fiscal Policy, [in:] M.S. Kumar, T. Ter-Minassian (eds.), Promoting Fiscal Discipline, IMF, 2007, pp. 34-58.

Działo J., Polityczne uwarunkowania jakości instytucji fiskalnych, Wydawnictwo Uniwersytetu Łódzkiego, Łódź 2009, p. 116.

Działo J., Czy Unia Europejska potrzebuje unii fiskalnej?, [in:] J. Sokołowski, A. Żabiński, Finanse publiczne, "Prace Naukowe UE we Wrocławiu”, Wrocław 2013, pp. 86-97.

European Commision, http://www.europa.eu (17.07.2015).

Eurostat, http://appsso.eurostat.ec.europa.eu/nui/submitViewTableAction.do, access: 27.01.2017.

Greene J.E., Public Finance. An International Perspective, World Scientific Publishing Co., Singapore 2012, p. 295. 
Jędrzejowicz T., Kitala M., Wronka A., Polityka fiskalna w kraju należącym do strefy euro. Wnioski dla Polski, [in:] NBP, Raport na temat pełnego uczestnictwa Rzeczypospolitej Polskiej w trzecim etapie Unii Gospodarczej i Walutowej. Warszawa 2009, pp. 39-58.

Kaliszuk E., Kontrowersyjny traktat fiskalny, “Unia Europejska.pl”, No. 2(213)/2012, p. 9.

Próchnicki L., Reguły fiskalne jako narzędzie utrzymania stabilności fiskalnej w Krajach Unii Europejskiej, "Studia Zarządzania i Finansów”, Wyższa Szkoła Bankowa w Poznaniu, No. 3/2012, pp. 27-51.

Report on the activities of the Regional Chambers of Audit and the execution of the budget by local government units for 2015. Part II, Warsaw 2016, p. 278.

Reinforcing Economic Policy Coordination, COM(2010).

Schick, A. Post-Crisis Fiscal Rules: Stabilising Public Finance while Responding to Economic Aftershocks, "OECD Journal on Budgeting", Vol. 10, No. 2/2010,

The Convergence Programme 2012 update (2012). Ministry of Finance. Warsaw, p. 64.

Ustawa z dnia 27 sierpnia 2009 r. o finansach publicznych (The Act of Public Finance), Dz. U. Nr 157 z 2009 r., poz. 1240.

Wójtowicz K., Problem konstrukcji optymalnej reguły fiskalnej w warunkach kryzysu finansowego, "Zeszyty Naukowe PTE”, No. 10/2011, pp. 137-15. 